\title{
A Comparison Of Corruption Perceptions: The Czech Republic And Sloakia
}

Jerry E. Wheat, (E-mail: jwheat@ius.edu), Indiana University Southeast

Brenda Swartz, Indiana University Southeast

Frank Wadsworth, Indiana University Southeast

\begin{abstract}
When the Soviet Union disintegrated in 1989 Czechoslovakia regained its independence from Soviet domination as a result of a so called "velvet revolution." Four years later in 1993 the two parts of Czechoslovakia separated in a "velvet divorce" to become two independent states: The Czech Republic and Slovakia. Slovakia was at the time less developed than the Czech Republic. Previous studies of corruption indicate that the less developed a country is the more corruption would be expected. This study uses data from the Business Environment and Economic Performance Survey (BEEPS) of the World Bank and the European Bank for reconstruction and Development to explore perceptions of corruption in the two countries.
\end{abstract}

\section{Introduction}

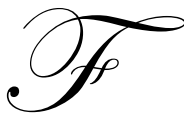

or most of the twentieth century the Czechs and the Slovaks were joined as one country: Czechoslovakia. The union was formed following World I and continued in the post-World War II era when the country became part of Soviet dominated Eastern Europe. Outside forces delineated the geographical boundaries of the country and had a great internal impact upon this not so sovereign nation. With the demise of the Soviet Union in 1989 the country regained its independence from Soviet domination as a result of a so called "velvet revolution." The Czech Republic became a sovereign independent nation exercising more internal control than they had for decades. Four years later in 1993 the two parts of Czechoslovakia by mutual agreement separated in a "velvet divorce" to become two independent states: Czech Republic and Slovakia. Part of the separation was attributed to the ethnic differences in different parts of the country. The Czech Republic is $81 \%$ ethnic Czech; Slovakia is 85\% ethnic Slovak (2003 CIA World Fact Book). During the past decade both countries have distanced themselves from a command economy, moved toward a market economy and joined the European Union May 1, 2004.

The split of Czechoslovakia offers a unique opportunity to study the perception of corruption in two countries previously joined together. As new institutions, regulations and laws evolve in each country, differing opportunities for corruption will also evolve. After the breakup of the Soviet Union, Czechoslovakia underwent a transition from a communist system to the nascent beginnings of a free market economy. This transition had not been completed by the 1993 breakup of the country into the Czech Republic and Slovakia thus creating additional uncertainty and an additional opportunity for corruption to develop in different ways. This study will focus on how corruption is perceived in the two countries several years after the breakup by comparing corruption perceptions of businesspeople in each country.

\section{Overview - Comparing Czech Republic and Slovakia}

The Czech Republic and Slovakia are different in many ways. The Czech Republic has twice the population of Slovakia. Demographically, both countries have a stagnant population growth rate. The Czech Republic has a slightly older population than Slovakia. The Czech Republic has a higher percent of population over 65 years old, and they have a higher percentage of female retirees than does Slovakia. Additionally, the Czech Republic has a greater migration rate than does Slovakia (CIA World Factbook, 2003). 
A source of concern is the unemployment rates in both countries. Long-term unemployment (those unemployed for more than two years) plagues both countries. "Unemployment among the Slovakian youth was a worryingly high 37 percent" (UN Concerned at Poverty, 2004.) The numbers of low skill jobs are diminishing, and there is a mis-match between the skill levels of the workers and the skill levels needed in the work place. Slovakia has about half a million Roma population, which either does not have access to post secondary education or does not participate. Acceptance into the EU will require both countries to adopt remedial programs to increase the education levels of their populous.

The Czech Republic has roughly twice the amount of electricity consumption of Slovakia. While both countries are exporters of electricity, the Czech Republic relies much more heavily upon fossil fuels for generation of electricity than does Slovakia. Slovakia derives more than half of its electricity production from nuclear sources.

\begin{tabular}{lll}
\hline & \multicolumn{1}{c}{ Czech Republic } & \multicolumn{1}{c}{ Slovakia } \\
\hline Population & 10.2 million & 5.4 million \\
GDP: Purchasing PowerParity & $\$ 155.9$ billion $(2002$ est.) & $\$ 66$ billion (2002 est.) \\
GDP-Real Growth Rate & $1.5 \%(2002$ est.) & $4 \%(2002$ est.) \\
GDP Per Capita & $\$ 15,300(2002$ est.) & $\$ 12,200(2002$ est.) \\
GDP Composition & & \\
$\quad$ Agriculture & $3.8 \%(2001)$ & $4.5 \%(2000)$ \\
$\quad$ Industry & $41 \%(2001)$ & $34 \%(2000)$ \\
$\quad$ Services & $55.2 \%(2001$ & $61.4 \%(2000)$ \\
Inflation Rate-Consumer Prices & $0.6 \%(2002)$ & $3.3 \%(2002$ est.) \\
Labor Force & 5.2 million $(1999$ est.) & 3 million (1999) \\
Unemployment Rate & $9.8 \%(2002)$ & $17.2 \%(2002$ est.) \\
Industrial Production Growth Rate & $3.5 \%(2002)$ & $4.4 \%(2002$ est.) \\
Electricity Production & 70.04 billion kwh & 30.29 billion kwh \\
& $(2001)$ & $(2001)$ \\
Electricity-Production by Source & & \\
$\quad$ Fossil Fuel & $76.1 \%$ & $30 \%$ \\
$\quad$ Hydro & 2.9 & $16 \%$ \\
$\quad$ Other & $1.0 \%(2001)$ & $0 \%(2001)$ \\
$\quad$ Nuclear & $20.0 \%$ & $53.7 \%$ \\
Electric Consumption & 55.6 billion kwh (2001) & 24.41 billion kwh (2001) \\
Electricity-Net Exports & 9.54 billion kwh (2001) & 3.76 billion kwh (2001) \\
Natural Gas-Proved Reserves & 3.057 billion cu m & 7.504 bullion cu m \\
& (January 2002 est.) & (January 2002 est.) \\
\hline
\end{tabular}

\section{The Importance of Corruption}

The World Bank in its analysis of corruption suggests that,

"When countries significantly alter their economic systems the disruption creates confusion and uncertainty as new institutions are being developed and people become accustomed to functioning in the new environment. Many positive institutions develop and evolve as a result of change. In this uncertain transition period, however, opportunities for corruption also develop and thrive in the void and confusion. In a 1996 speech to the World Bank's shareholders, Bank President James D. Wolfensohn 'placed corruption center stage as an obstacle to development, by drawing on evidence identifying corruption as a major disincentive to investment, and as a crippling tax on the poor' " (web.worldbank.org). 
Corruption is usually defined as the misuse of public office or money for private gain. Many, including major European countries, believe that corruption could help "grease the wheels" of a developing country. What corruption normally results in is a transfer of wealth from the poor and poverty stricken to the undeserving. Many of these countries allowed firms to deduct bribes to public officials as commissions because bribes were considered as a normal way of doing business. Recently the Organization for Economic Development (OECD) and the United Nations (UN) have offered resolutions that call for countries to disavow bribery as a way of doing business. In his 1996 speech in, Wolfensohn called corruption a cancer and called for a zero tolerance policy. Previously the Bank had chosen to not be involved in the corruption issue to avoid accusations of "political interference" in sovereign countries.

While it is difficult to compare corruption from country to country the World Bank constructed a corruption index score (value from 0-1.0) from the 12 most widely known international corruption indices. The data revealed that Central and Eastern Europe (CEE) had the $4^{\text {th }}$ highest score at .5 of the eight regions of the world studied. The Commonwealth of Independent States (CIS) was the highest score at .64 (Anticorruption in Transition, World Bank, 2000). A recent study by Ghemawat and Mallick indicates that corruption reduces trade in trade networks by as much as $11 \%$ (Ghemawat and Mallick 2003). The Ghemawat and Mallick study focused on the factors that increase or decrease trade between groups of countries.

In 1999, the World Bank and The European Bank for Reconstruction and Development (EBRD) decided to develop a survey of corruption perceptions in transition economies as a component of the ongoing World Business Environment Survey (WBES). As part of the WBES survey a transition economies component called Business Environment and Enterprise Performance Survey (BEEPS) was constructed to assesses in detail the various dimensions of governance. By unbundling governance into its many dimensions, BEEPS permits an in-depth empirical assessment of corruption perceptions, allows a more detailed quantitative assessment of corruption, and a more nuanced understanding of the causes of the problem. A 35 page survey instrument was created and administered in person by the A.C. Neilson Company. Managers in more than 4,000 firms in 22 transition countries in Eastern Europe and the Commonwealth of Independent States were surveyed between 1999-2000.

This study focuses on the role corruption plays in the Czech Republic and Slovakia. When the country broke apart in 1993, many commentators suggested that Slovakia would suffer economically from the split. The industrial capacity of the country was concentrated in the territory of the new Czech Republic suggesting that the new Slovak Republic would have greater unemployment difficulties. Slovakia also had a large Romany population that is undereducated and is mostly unemployed. Economic difficulties and chronic unemployment in a less developed country have traditionally lead to corruption in government. Our study looked at corruption in government from the perspective of when "additional payments" are required, what those "additional payments" are needed for and whether the payment had a significant impact on obtaining services.

Within the BEEPS Survey this paper examines the following aspects related to Corruption.

Additional Payments -- How frequently is the following statement true?

- Firms in my line of business usually know in advance how much the "additional payment" is

- More than one official will require payment of the same service

- If a firm makes an "additional payment" the service is delivered as agreed

- $\quad$ Analysis - By Country - Czech Republic vs. Slovakia - Table 1

Distribution of Payments

- $\quad$ To get connection to public services

- $\quad$ To get licenses and permits

- To deal with taxes and tax collection

- To gain government contracts

- To deal with customs and imports 
- To deal with the courts

- To deal with health/fire inspectors

- $\quad$ To influence the content of new laws, decrees and regulations

- $\quad$ Analysis by Firm Size and Country (Firm Size <100 employees and 100 or more employees) - Table 2

State Capture and the Impact of Corruption-What impact have the following forms of corruption had on your business?

- $\quad$ Central Bank mishandling of funds

- $\quad$ Sale of Parliamentary votes to private interests

- $\quad$ Sale of Presidential decrees to private interests

- $\quad$ Sale of decisions in the criminal courts

- $\quad$ Sale of decisions in the commercial courts

- $\quad$ Bribes to public officials to avoid regulations

- Patronage

- $\quad$ Contribution to political parties by private interests

- $\quad$ Analysis by Nature of Impact (Significant vs. Not Significant) and by Country - Table 3

\section{Data Analysis}

Analysis of the study data was done using Analysis of Variance (ANOVA). ANOVA tests for significant differences between group (country) means. For all of the analyses ANOVA examined differences between the Czech Republic and Slovakia on the particular question. For Table 1, the question was "How frequently is the following statement true?" and the analysis looked for differences between countries.

In Table 2 the question "Of the total unofficial payments per annum, what percentage would be spent to get..." and the analysis looked for differences between countries related to firm size on a series of eight different issues. Firms were categorized as having less than 100 employees or 100 or more employees. Smaller firms are more likely to need to spend money to receive public services than larger companies.

For Table 3, the analysis looked for differences between countries for questions related to "State Capture and Characteristics of Corruption and the Impact of Corruption..." again on a series of eight different issues. The impact of corruption should be more significant in Slovakia since it is less developed than the Czech Republic.

\section{Results}

Table 1 indicates that there is no statistical difference between the two countries on the questions related to additional payments. Answers to these questions ranged from almost to never in six increments. Almost, mostly and frequently were coded as equal to one, and seldom, sometimes and never were coded as equal to two. The means for each country's responses were tested for differences. $\mathrm{P}$ values for the means test indicate no significant differences between countries.

The analysis reported in Table 2 indicates there is a statistical difference for firms with less than 100 employees in the percentage of unofficial payments that is spent To Get Licenses and permits, To Gain Government Contracts and To Deal with Health/Fire Inspectors between the Czech Republic and Slovakia. A larger percentage of unofficial payments is spent in Slovakia on these activities. No statistical difference exists for firms with 100 or more employees between the countries for any of the activities described in the table. Survey participants were asked to categorize their responses in $10 \%$ increments and the data were coded as $1=0 \%-50 \%$ and $2=51 \%-100 \%$.

The analysis presented in Table 3 compares the impact of corruption based on an assumption of state capture in each country. Data for Table 3 were coded as a $1=$ no/minor impact and $2=$ significant/very significant impact 
State capture might be characterized by the idea of a "grabbing hand."-- a hand which grabs and takes control of another object or in the case of state capture other institutions. The traditional idea of state capture is that of the government officials taking control of business firms and extracting bribes or rent to pass legislation or regulations that favor one company over another. The process can also work the opposite direction. Firms can capture government by providing perks or bribes to officials to gain advantage. One summary of firms capturing government was provided by Valdimir Putin, President of the Russian Federation when speaking to a group of 21 new Russian oligarchs said:

"I only want to draw your attention straightaway to the fact that you have yourselves formed this very state, to a large extent through political and quasi-political structures under your control. So perhaps what one should do least of all is blame the mirror" (Hoffman, 2000).

Based on the BEEPS data, the World Bank constructed a state capture index for the 22 transition countries that participated in the survey. The state capture index for the Czech Republic was 11 and for Slovakia 23 indicating that Slovakia has more state capture of government by business than does the Czech Republic. (Note: The index was constructed as the average proportion of firms responding that their business had been directly affected by payments to public officials to influence decisions in the following institutions: parliament, executive apparatus, central bank, civil and criminal courts, and political parties (Hellman and Kaufman 2001). The BEEPS study does not clarify in which direction state capture occurs but the questions concerning impact of corruption assume that state capture has occurred. The question is designed is analyze the impact corruption has on state functions.

\section{Conclusion}

The idea that less developed countries are more susceptible to corruption and the impact of corruption is at least partially supported in the case of the Czech Republic and Slovakia. While knowledge of additional payments needs is not statistically different between the two countries, differences were found in other areas. Business people in both countries expect to make additional payments but in Slovakia, a different pattern of spending emerges for small companies with less than 100 employees. The perception in Slovakia is much stronger than in the Czech Republic that funds will have to be spent to obtain access to basic government regulatory and contract activities. In Slovakia the perception that corruption has a significant impact on government actions is much stronger than in the Czech Republic.

Since the two countries are ethnically different and Slovakia is less developed economically developed, we expected to find differences in perceptions and attitudes among business people about corruption and the BEEPS data appears to confirm this concept.

\section{References}

1. Hellman, Joel and David Kaufmann (2001), Confronting the Challenge of State Capture in Transition Economies, Finance and Development, September 2001, Volume 38, Number 3

2. Hoffman, David (2000), "Putin Aims to Assure Tycoons: Russian Disavows Pressure by Police," Washington Post (July 29), pp. A1.

3. Ghemawat, P. and Mallick, R. (2003), “The Industry-Level Structure of International Trade Networks," Harvard Business School Working Paper February 2003 version.

4. http://web.worldbank.org/WBSITE/EXTERNAL/NEWS/0,,contentMDK:20040922\%7EmenuPK:34480\% 7EpagePK:34370\%7EtheSitePK:4607,00.html.

5. UN Concerned at Poverty in Czech Republic, Hungary, Slovakia and Slovenia," April 7, 2004, www.eubusiness.com/afp/040407162805.yu8h4obl.

6. World Bank and European Bank for Reconstruction and Development, Business Environment and Economic Performance Survey, 1999. 
Table 1: How frequently is the following statement true?

\begin{tabular}{lcccc}
\hline & & N & Mean & P - value \\
\hline $\begin{array}{l}\text { Firms in my line of business usually know in advance how much } \\
\text { the "additional payment" is }\end{array}$ & Czech Republic & 69 & 1.64 & \\
\hline & Slovakia & 75 & 1.57 & .434 \\
\hline & Total & 144 & 1.60 & 1.27 \\
\hline $\begin{array}{l}\text { If a firm makes an "additional payment" the service is delivered as } \\
\text { agreed }\end{array}$ & Czech Republic & 71 & & \\
\hline & Slovakia & 75 & 1.29 & 1.28 \\
\hline & Total & 146 & & \\
\hline More than one official will require payment for the same service & Czech Republic & 51 & 1.69 \\
\hline & Slovakia & 69 & 1.64 \\
\hline & Total & 120 & 1.66 \\
\hline
\end{tabular}

Codes: 1 = Almost, Mostly, Frequently;

$2=$ Seldom, Sometimes, Never

Table 2: Distribution of Payments from the Corruption

Of the total unofficial payments per annum, what percentage would be spent for the following purpose?

\begin{tabular}{|c|c|c|c|c|c|}
\hline \multirow[t]{2}{*}{ Question } & \multirow[t]{2}{*}{ Response } & \multicolumn{2}{|c|}{ Czech Republic } & \multicolumn{2}{|c|}{ Slovakia } \\
\hline & & $\begin{array}{c}<100 \\
\text { employees } \\
\mathbf{N}=54\end{array}$ & $\begin{array}{c}100> \\
\text { employees } \\
N=6\end{array}$ & $\begin{array}{c}<100 \\
\text { employees } \\
\mathbf{N}=53\end{array}$ & $\begin{array}{c}100> \\
\text { employees } \\
\text { N=16 }\end{array}$ \\
\hline To get Connection to Public Services & $\begin{array}{c}0-50 \% \\
51-100 \% \\
\end{array}$ & $\begin{array}{c}98.2 \% \\
1.9 \%\end{array}$ & $\begin{array}{c}100 \% \\
0 \%\end{array}$ & $\begin{array}{c}98.2 \% \\
1.9 \% \\
\end{array}$ & $\begin{array}{c}93.8 \% \\
6.3 \% \\
\end{array}$ \\
\hline $\mathrm{P}$ - value & & .989 & .553 & & \\
\hline To get Licenses and Permits & $\begin{array}{c}0-50 \% \\
51-100 \% \\
\end{array}$ & $\begin{array}{l}92.7 \% \\
7.3 \% \\
\end{array}$ & $\begin{array}{l}83.4 \% \\
16.6 \% \\
\end{array}$ & $\begin{array}{l}77.2 \% \\
22.8 \% \\
\end{array}$ & $\begin{array}{l}68.8 \% \\
31.2 \% \\
\end{array}$ \\
\hline $\mathrm{P}$ - value & & .027 & .517 & & \\
\hline To deal with Taxes and Tax Collection & $\begin{array}{c}0-50 \% \\
51-100 \% \\
\end{array}$ & $\begin{array}{l}96.4 \% \\
3.6 \% \\
\end{array}$ & $\begin{array}{l}83.3 \% \\
16.7 \% \\
\end{array}$ & $\begin{array}{c}98.2 \% \\
1.9 \% \\
\end{array}$ & $\begin{array}{c}93.9 \% \\
6.1 \% \\
\end{array}$ \\
\hline $\mathrm{P}$ - value & & .573 & .473 & & \\
\hline $\begin{array}{l}\text { To gain Government } \\
\text { Contracts }\end{array}$ & $\begin{array}{c}0-50 \% \\
51-100 \% \\
\end{array}$ & $\begin{array}{l}64.9 \% \\
35.1 \% \\
\end{array}$ & $\begin{array}{l}66.7 \% \\
33.3 \% \\
\end{array}$ & $\begin{array}{l}86.9 \% \\
13.1 \% \\
\end{array}$ & $\begin{array}{l}87.6 \% \\
12.4 \% \\
\end{array}$ \\
\hline $\mathrm{P}$ - value & & .008 & .281 & & \\
\hline To deal with Customs and Imports & $\begin{array}{c}0-50 \% \\
51-100 \% \\
\end{array}$ & $\begin{array}{l}96.3 \% \\
3.7 \% \\
\end{array}$ & $\begin{array}{c}100 \% \\
0 \% \\
\end{array}$ & $\begin{array}{c}96.2 \% \\
3.8 \% \\
\end{array}$ & $\begin{array}{c}100 \% \\
0 \% \\
\end{array}$ \\
\hline $\mathrm{P}$ - value & & .985 & $\mathrm{n} / \mathrm{a}$ & & \\
\hline To deal with the Courts & $\begin{array}{c}0-50 \% \\
51-100 \% \\
\end{array}$ & $\begin{array}{c}100 \% \\
0 \% \\
\end{array}$ & $\begin{array}{c}100 \% \\
0 \% \\
\end{array}$ & $\begin{array}{c}98.1 \% \\
1.9 \% \\
\end{array}$ & $\begin{array}{c}100 \% \\
0 \% \\
\end{array}$ \\
\hline $\mathrm{P}$ - value & & .315 & $\mathrm{n} / \mathrm{a}$ & & \\
\hline To deal with Health/Fire Inspectors & $\begin{array}{c}0-50 \% \\
51-100 \% \\
\end{array}$ & $\begin{array}{c}94.6 \% \\
5.4 \% \\
\end{array}$ & $\begin{array}{c}100 \% \\
0 \% \\
\end{array}$ & $\begin{array}{c}100 \% \\
0 \% \\
\end{array}$ & $\begin{array}{c}100 \% \\
0 \% \\
\end{array}$ \\
\hline $\mathrm{P}$ - value & & .083 & $\mathrm{n} / \mathrm{a}$ & & \\
\hline $\begin{array}{l}\text { To influence the content of New Laws, } \\
\text { Decrees \& Regulations }\end{array}$ & $\begin{array}{c}0-50 \% \\
51-100 \% \\
\end{array}$ & $\begin{array}{c}100 \% \\
0 \% \\
\end{array}$ & $\begin{array}{c}100 \% \\
0 \% \\
\end{array}$ & $\begin{array}{c}100 \% \\
0 \% \\
\end{array}$ & $\begin{array}{c}100 \% \\
0 \% \\
\end{array}$ \\
\hline $\mathrm{P}$ - value & & $\mathrm{n} / \mathrm{a}$ & $\mathrm{n} / \mathrm{a}$ & & \\
\hline
\end{tabular}

$\mathrm{P}$-values are for the test of differences between the two countries mean percent response within a number of employees firm size. 
Table 3: Corruption-State Capture and the Impact of Corruption

\begin{tabular}{|c|c|c|c|c|c|}
\hline \multirow[b]{2}{*}{ Question } & \multicolumn{2}{|c|}{ Czech Republic } & \multicolumn{2}{|r|}{ Slovakia } & \multirow[b]{2}{*}{$\begin{array}{c}\mathbf{P} \text { - } \\
\text { value }\end{array}$} \\
\hline & $\begin{array}{l}\text { No/Minor } \\
\text { Impact }\end{array}$ & $\begin{array}{c}\text { Significant/Very } \\
\text { Significant Impact }\end{array}$ & $\begin{array}{l}\text { No/Minor } \\
\text { Impact }\end{array}$ & $\begin{array}{c}\text { Significant/Very } \\
\text { Significant Impact }\end{array}$ & \\
\hline Central Bank Mishandling of Funds & $\begin{array}{c}92 * \\
(87.6 \%)^{* *}\end{array}$ & $\begin{array}{c}13 \\
(12.4 \%) \\
\end{array}$ & $\begin{array}{c}59 \\
(62.8 \%) \\
\end{array}$ & $\begin{array}{c}33 \\
(37.2 \%) \\
\end{array}$ & .000 \\
\hline Sale of Parliamentary Votes & $\begin{array}{c}78 \\
(82.1 \%)\end{array}$ & $\begin{array}{c}17 \\
(17.9 \%)\end{array}$ & $\begin{array}{c}57 \\
(80.3 \%)\end{array}$ & $\begin{array}{c}14 \\
(19.7 \%)\end{array}$ & .767 \\
\hline Sales of Presidential Decrees & $\begin{array}{c}77 \\
(88.5 \%) \\
\end{array}$ & $\begin{array}{c}10 \\
(11.4 \%) \\
\end{array}$ & $\begin{array}{c}64 \\
(87.7 \%) \\
\end{array}$ & $\begin{array}{c}9 \\
(12.4 \%) \\
\end{array}$ & .872 \\
\hline Sale of Decisions in Criminal Court & $\begin{array}{c}86 \\
(90.5 \%) \\
\end{array}$ & $\begin{array}{c}9 \\
(9.5 \%) \\
\end{array}$ & $\begin{array}{c}57 \\
(71.3 \%) \\
\end{array}$ & $\begin{array}{c}23 \\
(28.8 \%) \\
\end{array}$ & .001 \\
\hline $\begin{array}{l}\text { Sale of Decisions in Commercial } \\
\text { Courts }\end{array}$ & $\begin{array}{c}81 \\
(91.0 \%) \\
\end{array}$ & $\begin{array}{c}8 \\
(9.0 \%) \\
\end{array}$ & $\begin{array}{c}59 \\
(74.7 \%) \\
\end{array}$ & $\begin{array}{c}20 \\
(25.3 \%) \\
\end{array}$ & .004 \\
\hline $\begin{array}{l}\text { Bribes to Public Officials to Avoid } \\
\text { regulations }\end{array}$ & $\begin{array}{c}82 \\
(91.1 \%)\end{array}$ & $\begin{array}{c}8 \\
(8.9 \%)\end{array}$ & $\begin{array}{c}65 \\
(71.5 \%)\end{array}$ & $\begin{array}{c}26 \\
(28.6 \%)\end{array}$ & .001 \\
\hline Patronage & $\begin{array}{c}79 \\
(84.0 \%)\end{array}$ & $\begin{array}{c}15 \\
(16.0 \%)\end{array}$ & $\begin{array}{c}62 \\
(67.4 \%)\end{array}$ & $\begin{array}{c}30 \\
(32.6 \%)\end{array}$ & .008 \\
\hline $\begin{array}{l}\text { Contribution to Political Parties by } \\
\text { Private Interests }\end{array}$ & $\begin{array}{c}84 \\
(94.4 \%) \\
\end{array}$ & $\begin{array}{c}5 \\
(5.6 \%) \\
\end{array}$ & $\begin{array}{c}67 \\
(79.8 \%) \\
\end{array}$ & $\begin{array}{c}17 \\
(20.3 \%) \\
\end{array}$ & .004 \\
\hline
\end{tabular}

$\mathrm{P}$-values are for the test of differences between the two countries mean response

* Numbers represent $\mathrm{N}$

** Percent of responses for the country 
Notes 